\title{
The Difference of Service Quality and Consumer Satisfaction on Traditional and Modern Wedangan (Survey On Warung Wedangan In Solo)
}

\author{
Marjam Desma Rahadhini \\ Faculty of Economics University of Slamet Riyadi \\ (UNISRI) \\ Surakarta, Indonesia \\ Email: m_rahadhini@yahoo.com
}

\author{
Lamidi \\ Faculty of Economics University of Slamet Riyadi \\ (UNISRI) \\ Surakarta, Indonesia \\ Email: lamidi71@gmail.com
}

\begin{abstract}
Warung wedangan can be categorized as an informal business, which exists specifically in Solo city. The development of wedangan or HIK (Hidangan Istimewa Kampung or Special Village Culinary) is progressing day to day. Initially, HIK is invoked as the icons of the lower level society, but now it is attracting the whole class of society regardless of status and position. In this study, traditional wedangan is characterized with the use of a cart and present a simple menu while modern one is characterized with a comfortable place, wi-fi available, and vary of menus. Using a survey, this study aims to know whether there are differences in service quality and customer satisfaction in traditional and modern wedangan, in an effort to improve those factors. The population of this study is the consumers of traditional side (represented by wedangan Pak Amir) and modern side (represented by wedangan Lawang Djoendjing). By using convenience sampling, the sample consists of 100 respondents (50 customers in both sides). The results show that (1) the quality of service significantly affects consumer satisfaction in the traditional and modern wedangan with $t$ value of 9.072 and $p$ value of $0.000<0.05$, (2) there is a significant difference in terms of service quality between traditional and modern wedangan with $t$ value of 2.835 and $p$ value of $0.006<0.05$, and (3) there is a significant difference in consumer satisfaction between traditional and modern wedangan with the $t$ value of 3.639 and $p$ value $0.000<0.05$.
\end{abstract}

Keywords: service quality, customer satisfaction, traditional and modern wedangan

\section{Introduction}

The informal sector is growing due to the multidimensional crisis occurred in Indonesia, which later brings a varied impact on the society. One of the informal segments in the Solo city is a culinary. Solo culinary is not only enjoyed by the residents of Solo but also the people from the outside area of Solo. One form of traditional culinary business in Solo is Warung HIK (Hidangan Istimewa Kampung or Special Village Culinary). HIK is usually set on the sidewalk or in front of random shops (Susanto and Sudiro, 2014). HIK offers various foods and beverages, such as coffee, tea, ginger, snacks, fried and cooked rice that have been equipped with a side dish in a small portion, and warm drinks (wedang).

Along with the changes in lifestyle and society eating habits, the traditional wedangan business has transformed into a more attractive form. The current transformation model of wedangan stalls has more good-looking representation. Several newstands have a cafe style. Some of them are designed with unique themes, such as a retro theme, latest themes, romantic atmosphere, garden party atmosphere, and others. It is also equipped with free wi-fi connection and live music to satisfy the consumers. One of traditional wedangan in the Solo city is wedangan Pak Amir that is located in Nusukan Solo. The concept applied is still habitual, using carts and sitting on the floor right on the side of the road. Unlike wedangan Lawang Djoenjing that categorized as a modern vendor, which has more effort to increase its customer satisfaction through improving the quality of service by providing a hot-spot, a comfortable place, and a complete food and beverages variation in accordance with the consumers tastes.

The concept of traditional and modern wedangan provides a variety of culinary options for the customers to choose. Moreover, within the selection, service quality and satisfaction are the factor that needs to be considered. It is because culinary business has several aspects to consider, namely taste and benefits of the products and services offered to the consumer when they purchase the culinary products. Basith, Kumadji and Hidayat (2014), states that if the service, received or perceived, can fulfill the expectations of the customers, then the perceived quality would be good and can satisfy the customer. Conversely, if the received quality is less than expected, the perceived quality of the product would be poor or unsatisfactory. 


\section{Literature Review}

Marketing is the activity performed by a company in the effort to maintain the company's survival and gaining profit. "Marketing is a social and managerial process by individuals and groups to obtain what they need and want through creating, offering, and freely exchanging products and services or value of other" (Kotler, 2007). "Marketing connects sellers with potential buyers, thus the product will not be delivered to the seller" (Kartajaya, 2009). Thus, marketing is a social and managerial process by which individuals and groups achieve what they need and want by creating, offering, and exchanging products of value with others. Marketing objectives are to meet and satisfy the needs and desires of the consumers, and how individuals, groups, and organizations select, buy, use a product, ideas, or experiences within an effort to satisfy their needs and desires (Kotler, 2007).

Kotler (2007) states that satisfaction is a happy or disappointed feeling resulted from comparing the perceived performance of the product (or results) against the expectations of a person. Customer satisfaction is affected by perceived fairness, the expectations created by the consumers, and the actual quality of the service. Satisfaction can be affected by the comparison on services quality provided and expected by the customer. Consumer satisfaction is an evaluation of post-purchase that, at least, gives the equal outcomes or exceeds consumer expectations. Meanwhile, dissatisfaction arises when the results do not meet consumer expectations (Tjiptono, 2006). Customers are satisfied if the consumers' wishes fulfilled as what they expect. An additional value of a product will make the consumers become more satisfied and likely increase the chance for a new consumer to be a loyal client of the product in a long term. Customer satisfaction can be affected by various factors, namely: product quality, service, sales activities, and the value of the company.

The quality of service is an assessment standard where the ability, performance, reliability, maintainability, and characteristics of a service can be measured (Yamit, 2005). The quality of service is a service performed by the company as an effort to provide a satisfactory feeling and developing trust on customers, while making the customers feel valuable or acknowledged in a suitable form (Ruslan, 2006). "Service quality is the extent to the which a service offered can satisfy the expectations of the user" (Shanka, 2012). Parasuraman et al. (1988) states that quality is a form of attitude, related but not the same as satisfaction that is the result of a comparison between expectations of the actual performance. According to Parasuraman, service quality is formed by five dimensions, namely: reliability, assurance, responsiveness, empathy, and tangibility. The quality of service can be determined by comparing consumers' perception of the perceived services received from actual service provided by the company.

\section{Research Method}

This research is conducted in wedangan Lawang Djoenjing and Pak Amir's that located at Solo City. The background in choosing the object is because both shops are known for being one of the famous wedangans hops in Solo, and both of them are representative because they offer various kinds of menu and have a lot of consumers.

The number of population in this study is unknown (non-probabibility sampling). The population of this research is the consumers of wedangan Lawang Djoenjing and wedangan Pak Amir. While the sample is the partial or representative of the population studied (Arikunto, 2006). In an unknown exact number of the population, the sample took depends on the expected level of significance and error. For the unidentified population, determining the research sample can use the Leedy's formula, and after the calculation, it is determined that the number of samples as much as 100 respondents.

The sampling technique uses a convenience sampling method. To get a sample that consists of 100 respondents, the researchers distribute the questionnaires to consumers who come to wedangan Lawang Djoenjing and wedangan Pak Amir with a proportion of 50 consumers of wedangan Lawang Djoenjing and 50 consumers of wedangan Pak Amir. The research instrument is tested using the validity test (to check if the questionnaire used is relevant/valid) and the reliability test (to test whether the questionnaire is reliable). The classical assumption test is conducted to determine whether there is a deviation against the classical assumption with multicollinearity test, autocorrelation, heteroscedasticity, and normality.

To test the hypotheses, multiple linear regression test and independent sample t-test test are conducted to know whether there is a difference in terms of service quality and consumer satisfaction at wedangan Lawang Djoenjing and wedangan Pak Amir.

\section{Result and Discussion}

The results show that the 5 items of service quality instrument the p-value obtained is $<0.05$ thus all item of the statement is proved to be valid. 5 items of the client satisfaction instrument also obtained p-value $<0.05$ thus, all statement items are proved to be valid. The reliability test results obtained show a Cronbach Alpha value > 0.60 (quality of service's value is 0.667 and customer satisfaction value is 0.704 ) thus all statements are proved to be reliable.

The consequence of classical assumption test shows that from multicollinearity test, it is found that service quality variable has a tolerance value of $1.00>0,1$ and VIF value is $1.00<10$, thus there is no multi-collinearity. For autocorrelation test, it is found that p-value is $1.00>0.05$ thus there is no autocorrelation. For heteroscedasticity test with Glejser test obtained a p-value of service quality of $0.691>0.05$ thus the data is free of heteroscedasticity. Furthermore, the normality test using Kolmogorov-Smirnov results show that all variables used in this study are normally distributed because the p-value is $0.820>0.05$.

The test for hypothesis 1 is conducted using multiple linear regression to know the effect of service quality on consumer satisfaction at wedangan Lawang Djoenjing and wedangan Pak Amir, obtained a regression function of $\mathrm{Y}=$ $8.994+0.546 \mathrm{X}$, which interpreted as follows: 
- The value of the constant (a) is marked positive. That is 8.994 this means that if the quality of service is equal to zero then the consumer satisfaction is 8.994 .

- The value of service quality regression coefficient $(\mathrm{X})$ is equal to 0.546 . This means that the higher degree of service quality will increase consumer satisfaction.

The result of t-test shows that the service quality has a $t$ value of 9.072 with $p$-value of $0.000<0.05$ hence the $H_{o}$ is rejected, it means that the service quality have a significant effect on the consumer satisfaction at wedangan Lawang Djoenjing and wedangan Pak Amir. The result of the F test (model accuracy) shows a p-value of $0.000<0.05$ thus $\mathrm{H}_{\mathrm{o}}$ is rejected that means the regression model is fit in predicting the effect of service quality to customer satisfaction at wedangan Lawang Djoenjing and wedangan Pak Amir. The result of coefficient of determination shows an adjusted $\mathrm{R}$ square value equal to 0.451 which mean that $45.1 \%$ variance in service quality in wedangan Lawang Djoenjing and wedangan Pak Amir can be explained by consumer purchasing decision; while $54.9 \%$ is affected by other variables outside the research model, for examples: price, subjective norm and perception.

The testing of hypothesis 2 and 3 is using independent sample t-test to know the difference of modern and traditional wedangan in terms of the service quality and consumer satisfaction perceived by the consumer of Lawang Djoenjing and Pak Amir.

1. The difference of service quality between modern and traditional wedangan on consumer of Lawang Djoenjing and Pak Amir, the result shows $t$ value through equal variances assumed (assumed by two equal variance) 2.835 with $\mathrm{p}$ value $0.006<0.05$, which mean that there is a significant difference of service quality between modern vendor (Lawang Djoendjing) and traditional vendor (Pak Amir).

2. The difference of consumer satisfaction between modern and traditional business. Among the consumer of Lawang Djoenjing and Pak Amir, the $t$ value obtained through equal variances assumed (assumed two equal variance) is equal to 3.639 with $p$ value 0.000 $<0.05$ this mean that there is a significant difference of consumer satisfaction between modern one (Lawang Djoendjing) and another side (Pak Amir).

\section{Research Implications}

The implications of this research can be showed that:

1. The result confirmed that the service quality has a significant effect on customer satisfaction at modern merchant (Lawang Djoendjing) and traditional one (Pak Amir) with $\mathrm{t}$ value equal to 9.072 with $\mathrm{p}$ value $0.000<0.05$, thus hypothesis 1 is supported. The implication of this research is, in order to improve customer satisfaction is through the service quality, Lawang Djoenjing and Pak Amir are suggested to maintain the quality of service through a friendly service and giving a fast response to the customers' orders.

2. The result indicated that there is a significant difference of service quality between modern and traditional vendors with $\mathrm{t}$ value equals to 2.835 and $\mathrm{p}$ value $0.006<0.05$. Thus, hypothesis 2 is supported. The average result of service quality Lawang Djoenjing is 20.42 and average quality of service at traditional Pak Amir is 18.92. This shows that the quality of service in Lawang Djoenjing is better than the quality of service in Pak Amir. This proves that in service quality a modern one provides a faster and more accurate service because every order is adjusted with a table number or order number. Therefore the service became faster and better and every order is directly inserted into note. Thus payment process became faster. In addition, services provided in modern one found to be neat and employees are more attractive.

3. The result showed that there is a significant difference of consumer satisfaction between Lawang Djoendjing and Pak Amir with t value equals to 3.639 and $p$ value $0.000<0.05$. Thus, hypothesis 3 is supported. The average result of consumer satisfaction on Lawang Djoenjing is 20.50 whereas the average of consumer satisfaction on Pak Amir is 18.98. This shows that consumer satisfaction in modern one is better than consumer satisfaction in traditional. This proves that in the consumer in modern side more satisfied than in other side. It is because of the cleanliness of the room and a good layout, that makes the consumers in modern vendor feel more comfortable. Moreover, it is also equipped with wi-fi connection and live music that make the atmosphere become more convenient.

\section{Conclusion}

Based on the result, it can be concluded that the improvement of service quality will significantly increase customer satisfaction. It is also can be performed by modern (Lawang Djoenjing) and traditional vendor (Pak Amir) by maintaining the quality of service through a friendly customer service and a fast response to the consumers' order. In addition, modern and traditional vendor are expected to maintain a better service quality, traditional one needs to improve the quality of service, especially within the appearance of its employees and hospitality of the employees service. The important thing to do by modern and traditional business is to maintain their customer satisfaction. It is suggested for the traditional one to improve the hygiene or adding some additional facilities by providing a $\mathrm{Wi}-\mathrm{Fi}$ and a live music for the consumers. 


\section{References}

[1] Arianty, N. 2013. “Analisis Perbedaan Pasar Modern dan Pasar Tradisional Ditinjau dari Strategi Tata Letak (Lay Out) dan Kualitas Pelayanan untuk Meningkatkan Posisi Tawar Pasar Tradisional". Jurnal Manajemen dan Bisnis. Vol 3 No 1, h. 18-29.

[2] Arikunto, Suharsimi. 2006, Prosedur Penelitian Suatu Pendekatan Praktik, Rineka Cipta, Jakarta.

[3] Assael, H., 1998, Consumer Behavior and Marketing Action, $6^{\text {th }}$ ed. Cincinnati, OH: South-Western College Publishing.

[4] Assauri, Sofjan. 2004, Manajemen Pemasaran: Dasar, Konsep dan Strategi, Grafindo Persada. Jakarta.

[5] Basith, Abdul, Srikandi Kumadji dan Kadarisman Hidayat. 2014. "Pengaruh Kualitas Produk dan Kualitas Pelayanan terhadap Kepuasan Pelanggan dan Loyalitas Pelanggan (Survei pada Pelanggan De'Pans Pancake and Waffle di Kota Malang)".Jurnal Administrasi Bisnis (JAB). Vol. 11 No. 1, h. 1-8.

[6] Bell, S. J., Auh S, Smalley, K., 2005, "Customer Relationship Dynamics: Service Quality and Customer Loyalty in the Context of Varying Levels of Customer Expertise and Switching Costs", Journal of the Academy of Marketing Science, 33(2), 169-183.

[7] Ghozali, Imam. 2005, Aplikasi Analisis Multivariate Dengan Program SPSS, Badan Penerbit Universitas Diponegoro, Semarang.

[8] Han, H., and Ryu, K., 2009, "The Roles of the Physical Environment, Price Perception, and Customer Satisfaction in Determining Customer Loyalty in the Restaurant Industry", Journal of Hospitality and Tourism Research, Vol. 33(4): 487510.

[9] Jang, S., Namkung, Y., 2009, "Perceived Quality, Emotions and Behavioral Intentions: Application of an Restaurants", Journal of Business Research, Vol 62 (4): 451-460.

[10] Kartajaya, Hermawan. 2009. On Marketing. Gramedia Pustaka Utama. Jakarta.

[11] Kotler, Philip, dan Armstrong, Garry, 2006, Principles of Marketing, $11^{\text {th }}$ edition, Prentice Hall, New Jersey.

[12] Mandasari, Vina dan Bayu A. T., 2011, "Analisis Kepuasan Konsumen terhadap Restoran Cepat Saji melalui Pendekatan Data Mining: Studi Kasus XYZ”, Jurnal: Generic, Universitas Sriwijaya, Vol. 6(1), Januari, hal. 25-28.

[13] Parasuraman, A., Valerie A. Zeithaml, and Leonard L. Berry, 1988, "SERVQUAL: A Multiple Item Scale for Measuring Customer Perception of Service Quality", Journal of Marketing, Vol.64,12-40.
[14] Rangkuti, Freddy. 2009. Measuring Customer Satisfaction: Teknik Mengukur\&Strategi Meningkatkan Kepuasan Pelanggan. Gramedia Pustaka Utama. Jakarta.

[15] Rousan A., Ramzi M., dan Mohamed B., 2010, "Customer Loyalty and the Impacts of Service Quality: The Case of Five Star Hotels in Jordan", International Journal of Human and Social Sciences, Vol.5 No.13(2): 886-892.

[16] Shanka, Mesay Sata. 2012. "Bank Service Quality, Customer Satisfaction and Loyalty in Ethiopian Banking Sector". Journal of Business Administration and Management Sciences Research. Vol. 1(1), pp. 001-009.

[17] Simamora, Bilson. 2009, Memenangkan Pasar dengan Pemasaran Efektif dan Profitabel, Gramedia Pustaka Utama, Jakarta

[18] Sugiyono. 2012. Statistika Untuk Penelitian. Alfabeta. Bandung.

[19] Susanto, Edy dan Sudiro. 2014. "HIK Naik Kelas (Kajian Sosial Ekonomi Warung HIK (Hidangan Istimewa Kampung) di Kota Surakarta)) Sebagai Usaha Kecil Menengah Berbasis Kerakyatan”. Jurnal Sainstech Politeknik Indonusa Surakarta. Vol. 1(2), h. $1-12$.

[20] Tjiptono, Fandy. 2008, Service. Quality. and Satisfaction. Andi Offset. Yogyakarta.

[21] Wan I Lee, and Chi Lung Lee, 2011, “An Innovative Information and Relationship Between Service Quality, Customer Value, Customer satisfaction, and Purchase Intention", International Journal of Innovative Computing Information and Control, Vol 7, No 7(a).

[22] Yamit, Zulian. 2005, Manajemen Kualitas Produk dan Jasa. Edisi 1, Ekonisia, FE UII, Yogyakarta. 